\title{
Schiff Base Conjugate of 5-Fluoroisatin with Thiophene-2-Ethylamine and its Mannich Bases: Synthesis, Molecular Docking, and Evaluation of in vitro Anti-inflammatory and Anti-tubercular Activity
}

Bhushan Dnyandeo Varpe, Shailaja Bhanudas Jadhav

Progressive Education Society's, Modern College of Pharmacy, Nigdi, Pune, Maharashtra, INDIA.

\begin{abstract}
Objectives: To synthesize Schiff base conjugate of 5-Fluoroisatin with thiophene-2-ethylamine and its Mannich bases and screen for anti-inflammatory and anti-tubercular activity. Materials and Methods: The compounds were synthesized by Schiff and Mannich base reactions. The anti-inflammatory activity was studied by analyzing the percentage inhibition of denaturation of Bovine Serum Albumin and anti-tubercular activity using the Almar blue assay against Mycobacterium tuberculosis (MTB H37Rv). To understand the interactions of compounds with receptors and pharmacokinetic properties, in silico studies were performed. Results: The compound ITF $5(80.08 \%)$ showed good anti-inflammatory activity. Also, compound ITF 5 (MIC: $6.25 \mu \mathrm{g} / \mathrm{ml}$ ) was found most active against MTB H37Rv (ATCC-27294). Conclusion: Compounds showed good anti-inflammatory activities and relatively weak anti-tubercular activities as compared
\end{abstract}

to standards. The compounds ITF 5 with $\mathrm{N}$-phenylpiperazine containing Mannich base showed better anti-inflammatory and anti-tubercular activity as compared to other compounds.

Key words: 5-Fluoroisatin, Anti-inflammatory activity, Docking, Anti-tubercular activity, In silico ADME.

Correspondence

Mr. Bhushan D Varpe,

Progressive Education Society's, Modern College of Pharmacy, Nigdi, Pune-411044, Maharashtra, INDIA.

Email id: bhushanvarpe@outlook.com;

ORCID: 0000-0002-4187-9379

DOI: $10.5530 /$ ijpi.2021.2.34

\section{INTRODUCTION}

Fluorinated isatin derivatives were extensively investigated for antitubercular activity as the prior studies have shown that the substitution of fluorine at the C-5 position of the isatin moiety have a significant effect on anti-tubercular activity. ${ }^{1-4}$ Anti-tubercular and anti-inflammatory activities of heterocyclic hybrids with isatin (indole-2,3-dione) are being studied extensively. ${ }^{5,6}$ The Mannich bases of isatin shows potent anti-tubercular activities in previous studies. ${ }^{7,8}$

Anti-tubercular and anti-inflammatory properties of isatin and thiophene derivatives have been reported in the literature. ${ }^{9-14}$ Tenidap, an indole and thiophene nucleus-containing molecule reached in a clinical trial for the treatment of anti-inflammatory activity. ${ }^{15,16}$ The indole derivative with a thiophene-containing fragment at C-3, a halogen group at $\mathrm{C}-5$, and substitutions on the nitrogen atom nitrogen atom present in tenidap, as well as the synthesized molecules of this study. The chemical structure of the tenidap, an anti-inflammatory agent, and the previous studies indicating the significance of fluorinated isatins as anti-tubercular agents encouraged us to design the molecules of the present study.

The molecules that can prevent protein denaturation, are considered desirable candidates for anti-inflammatory drug development. Estimation of inhibition of protein denaturation is one of the methods for studying anti-inflammatory activity. ${ }^{17-20}$ The synthesized conjugates were evaluated for their anti-inflammatory activity by analyzing percentage inhibition of denaturation of Bovine Serum Albumin (BSA) and compared with standard diclofenac sodium.
In this research work, we have performed anti-tubercular and antiinflammatory activity evaluation of ethylene tethered 5-fluoroisatin Schiff's base conjugate with thiophene-2-ethylamine, and further in silico docking and Absorption, Distribution, Metabolism, and Excretion (ADME) studies.

\section{MATERIALS AND METHODS}

The Schiff base conjugate (ITF 1) was synthesized by treating thiophene2-ethylamine with 5-Fluoroisatin in the presence of acetic acid as a catalyst. Mannich bases of synthesized Schiff base were prepared by treating ITF 1 with formaldehyde $37 \%$ and secondary amines. Melting Points were analyzed by using Thiele's tube and are uncorrected. Infrared (IR) spectra were recorded on an IR spectrometer Bruker ALPHA spectrometer. NMR spectra were recorded on Bruker 400 spectrometer in DMSO as a solvent.

\section{Synthesis of isatin and thiophene-2-ethylamine Schiff base (ITF 1)}

Equimolar quantities of 5-Fluoroisatin $(0.01 \mathrm{M})$ in $5 \mathrm{ml}$ of warm ethanol and thiophene-2-ethylamine $(0.01 \mathrm{M})$ were mixed. Two drops of acetic acid were added to the mixture and stirred at 500 Revolutions Per minute (RPM) for $6 \mathrm{hr}$. The resultant yellow solid was washed with ethanol and recrystallized from the chloroform-methanol mixture. 


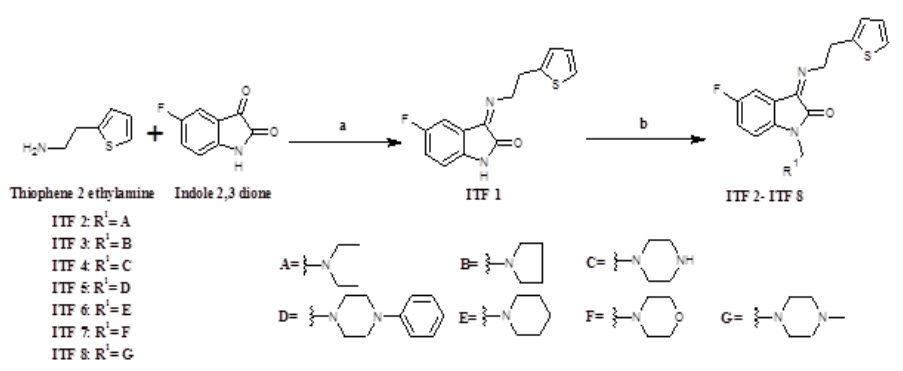

Scheme 1: Synthesis of Schiff's base of 5-Fluoroisatin with thiophene-2-ethylamine and its Mannich bases

\section{Synthesis of Mannich bases of thiophene containing} isatin derivatives (ITF 2-8)

A slurry consisting of the ITF $1(0.001 \mathrm{~mol})$, ethanol $(2 \mathrm{ml})$, and $37 \%$ formaldehyde $(2 \mathrm{ml})$ was prepared. Secondary amine $(0.001 \mathrm{~mol})$ was added to the above slurry dropwise over $15 \mathrm{~min}$, with cooling and stirring. The reaction mixture was stirred at $60 \mathrm{RPM}$ at room temperature for $1 \mathrm{hr}$. The reaction mixture was then warmed for $15 \mathrm{~min}$ on a steam bath. Then the contents were cooled and the obtained product was recrystallized from chloroform-hexane. ${ }^{21-24}$

5-fluoro-3-((2-(thiophen-2-yl)ethyl)imino)indolin-2-one (ITF 1)

Yield: $74 \%$; M.P.: $179-180^{\circ} \mathrm{C}$, IR $\left(\mathrm{cm}^{-1}\right)$ : 3243.5191, 3050.4939, 2950.5436 , $1731.3630,1657.4411,1473.4838,1354.3680,1265.5851,1175.6082$, $1041.0658,830.9277,746.7976,{ }^{1} \mathrm{H}-\mathrm{NMR}(400 \mathrm{MHz}, \mathrm{DMSO}) \delta 10.76(\mathrm{~s}, 1 \mathrm{H})$, $7.51(\mathrm{dd}, J=8.6,2.4 \mathrm{~Hz}, 1 \mathrm{H}), 7.24(\mathrm{dd}, J=5.0,1.1 \mathrm{~Hz}, 1 \mathrm{H}), 7.19$ (dd, $J=9.0,2.4 \mathrm{~Hz}, 1 \mathrm{H}), 6.9-6.83(\mathrm{~m}, 2 \mathrm{H}), 6.81(\mathrm{dd}, J=8.6,4.4 \mathrm{~Hz}$, $1 \mathrm{H}), 4.13(\mathrm{t}, J=6.6 \mathrm{~Hz}, 2 \mathrm{H}), 3.27(\mathrm{t}, 2 \mathrm{H}) .{ }^{13} \mathrm{C}-\mathrm{NMR}(126 \mathrm{MHz}, \mathrm{DMSO})$ $\delta 159.62,153.62,144.11,142.68,136.27,135.76,129.83,127.22,125.72$, $124.65,114.42,113.25,53.26,31.58$, ESI-MS: $\mathrm{M}+1 \mathrm{M} / z 275.32$.

1-((diethylamino)methyl)-3-(2-(thiophen-2-yl)ethylimino)-5-fluoroindolin-2-one (ITF 2)

Yield: $88 \%$; M.P.: $186-188^{\circ} \mathrm{C},{ }^{1} \mathrm{H}-\mathrm{NMR}(400 \mathrm{MHz}, \mathrm{DMSO}) \delta 7.67-7.57$ $(\mathrm{m}, 2 \mathrm{H}), 7.30-7.18(\mathrm{~m}, 2 \mathrm{H}), 6.97(\mathrm{dd}, J=8.4,2.2 \mathrm{~Hz}, 1 \mathrm{H}), 6.71(\mathrm{t}, J=8$ $\mathrm{Hz}, 1 \mathrm{H}), 4.52(\mathrm{~s}, 2 \mathrm{H}), 4.31(\mathrm{t}, J=6.5 \mathrm{~Hz}, 2 \mathrm{H}), 3.02(\mathrm{t}, J=6.5 \mathrm{~Hz}, 2 \mathrm{H}), 2.71$ $(\mathrm{t}, J=6.3 \mathrm{~Hz}, 4 \mathrm{H}), 1.08(\mathrm{t}, J=6.2 \mathrm{~Hz}, 6 \mathrm{H}) \cdot{ }^{13} \mathrm{C}-\mathrm{NMR}\left(126 \mathrm{MHz}, \mathrm{CDCl}_{3}\right)$ $\delta 153.80,152.11,141.97,130.21,128.94,127.90,127.53,127.38,127.30$, $127.07,110.55,107.57,64.12,53.38,38.28,29.70,22.00$ ESI-MS: $\mathrm{M}+1 \mathrm{M} / \mathrm{z} 360.91$

3-(2-(thiophen-2-yl)ethylimino)-5-fluoro-1-((pyrrolidin-1-yl)methyl) indolin-2-one (ITF 3)

Yield: 74 \%; M.P.: $167-169^{\circ} \mathrm{C}, \operatorname{IR}\left(\mathrm{cm}^{-1}\right): 3190.9644,2950.6964,1731.5390$, $1699.1109,1557.6974,1434.9658,1265.6523,1175.6161,871.6475$, 728.1632, ${ }^{1} \mathrm{H}-\mathrm{NMR}$ (400 MHz, DMSO) $\delta$ 7.65-7.51 (m, 2H), 7.40-7.20 $(\mathrm{m}, 2 \mathrm{H}), 6.90(\mathrm{t}, J=7.9 \mathrm{~Hz}, 1 \mathrm{H}), 6.71(\mathrm{dd}, J=8.5,2.2 \mathrm{~Hz}, 1 \mathrm{H}), 4.68$ $(\mathrm{s}, 2 \mathrm{H}), 4.20(\mathrm{t}, J=6.6 \mathrm{~Hz}, 2 \mathrm{H}), 3.28(\mathrm{t}, J=6.6 \mathrm{~Hz}, 2 \mathrm{H}), 2.89-2.84(\mathrm{t}$, $J=4.0 \mathrm{~Hz}, 4 \mathrm{H}), 1.81(\mathrm{t}, J=4.0 \mathrm{~Hz}, 4 \mathrm{H}) .{ }^{13} \mathrm{C}-\mathrm{NMR}\left(126 \mathrm{MHz}, \mathrm{CDCl}_{3}\right)$ $\delta 183.15,158.90,151.59,151.10,138.39,129.16,125.35,123.96,120.08$, $117.61,116.35,111.76,62.37,51.57,50.74,49.18,49.11$ ESI-MS: M+1 $M / z 358.73$.

3-(2-(thiophen-2-yl)ethylimino)-5-fluoro-1-((piperazin-1-yl)methyl) indolin-2-one (ITF 4)

Yield: $80 \%$; M.P.: $159-160^{\circ} \mathrm{C},{ }^{1} \mathrm{H}-\mathrm{NMR}(400 \mathrm{MHz}, \mathrm{DMSO}) \delta 7.75-7.62$ $(\mathrm{m}, 2 \mathrm{H}), 7.32-7.17(\mathrm{~m}, 2 \mathrm{H}), 6.95(\mathrm{t}, J=8 \mathrm{~Hz}, 1 \mathrm{H}), 6.71(\mathrm{dd}, J=8.1,2.4$ $\mathrm{Hz}, 1 \mathrm{H}), 4.75(\mathrm{~s}, 2 \mathrm{H}), 4.70-4.65(\mathrm{~m}, 1 \mathrm{H}), 4.31(\mathrm{t}, J=6.6 \mathrm{~Hz}, 2 \mathrm{H}), 3.15$ $(\mathrm{t}, J=6.6 \mathrm{~Hz}, 2 \mathrm{H}), 2.89(\mathrm{t}, 4 \mathrm{H}), 2.78(\mathrm{t}, 4 \mathrm{H}) .{ }^{13} \mathrm{C}-\mathrm{NMR}(126 \mathrm{MHz}, \mathrm{DMSO})$ $\delta 179.99,162.79,159.88,151.74,143.94,132.82,127.29,126.84,123.58$, $121.67,112.95,112.69,66.68,66.66,59.51,53.89,49.56$, ESI-MS: $\mathrm{M}+1 \mathrm{M} / z 373.80$ 3-(2-(thiophen-2-yl)ethylimino)-5-fluoro-1-((4-phenylpiperazin-1-yl) methyl)indolin-2-one (ITF 5)

Yield: $72 \%$; M.P. $181-183^{\circ} \mathrm{C}, \mathrm{IR}\left(\mathrm{cm}^{-1}\right): 3080.0084,2955.5341,2922.6091$, 1726.0572 , 1597.1087, 1463.0840, 1276.7926, 1191.2413, 1056.6402, 988.5214, $730.3508{ }^{1} \mathrm{H}-\mathrm{NMR}(400 \mathrm{MHz}, \mathrm{DMSO}) \delta 7.58(\mathrm{dd}, J=8.5,2.2$ $\mathrm{Hz}, 1 \mathrm{H}), 7.32(\mathrm{td}, J=9.0,2.3 \mathrm{~Hz}, 1 \mathrm{H}), 7.27-7.19(\mathrm{~m}, 2 \mathrm{H}), 7.10(\mathrm{t}, J=7.9$ $\mathrm{Hz}, 2 \mathrm{H}), 6.95-6.77(\mathrm{~m}, 4 \mathrm{H}), 6.67(\mathrm{t}, J=7.2 \mathrm{~Hz}, 1 \mathrm{H}), 4.43(\mathrm{~s}, 2 \mathrm{H}), 4.18$ $(\mathrm{t}, J=6.5 \mathrm{~Hz}, 2 \mathrm{H}), 3.29(\mathrm{t}, J=6.5 \mathrm{~Hz}, 2 \mathrm{H}), 3.00(\mathrm{t}, 4 \mathrm{H}), 2.59(\mathrm{t}, J=5.0$ $\mathrm{Hz}, 4 \mathrm{H}) .{ }^{13} \mathrm{C}-\mathrm{NMR}\left(126 \mathrm{MHz}, \mathrm{CDCl}_{3}\right) \delta 168.90,166.18,164.17,163.48$, $163.10,152.18,137.08,136.29,131.90,131.84,128.62,128.29,124.60$, $111.73,107.04,102.50,40.22,40.10,31.11,29.70,24.13$; ESI-MS: $\mathrm{M}+1 \mathrm{M} / \mathrm{z} 449.85$

3-(2-(thiophen-2-yl)ethylimino)-5-fluoro-1-((piperidin-1-yl)methyl) indolin-2-one (ITF 6)

Yield: 67 \%; M.P.: $177-179^{\circ} \mathrm{C}$, $\operatorname{IR}\left(\mathrm{cm}^{-1}\right): 3150.5396,2950.5658,1744.2803$, $1651.5392,1598.2056,1473.2304,1257.4454,908.7893,810.6097$, 720.5053, ${ }^{1} \mathrm{H}-\mathrm{NMR}$ (400 MHz, DMSO) $\delta 7.59-7.50(\mathrm{~m}, 2 \mathrm{H}), 7.32-7.15$ $(\mathrm{m}, 2 \mathrm{H}), 6.97(\mathrm{t}, J=7.9 \mathrm{~Hz}, 1 \mathrm{H}), 6.71(\mathrm{dd}, J=8.5,2.2 \mathrm{~Hz}, 1 \mathrm{H}), 4.71$ $(\mathrm{s}, 2 \mathrm{H}), 4.10(\mathrm{t}, J=6.6 \mathrm{~Hz}, 2 \mathrm{H}), 3.25(\mathrm{t}, J=6.5 \mathrm{~Hz}, 2 \mathrm{H}), 2.73(\mathrm{t}, 4 \mathrm{H}), 1.66$ $(\mathrm{m}, 6 \mathrm{H}) .{ }^{13} \mathrm{C}-\mathrm{NMR}\left(126 \mathrm{MHz}, \mathrm{CDCl}_{3}\right) \delta 169.11,163.53,158.72,141.55$, $140.67,129.41,128.06,118.89,117.01,115.97,113.61,113.16,66.79$, 66.61, 55.02, 54.15, 52.67, 50.94; ESI-MS: M+1 M/z 372.88

3-(2-(thiophen-2-yl)ethylimino)-5-fluoro-1-(morpholinomethyl)indolin-2-one (ITF 7)

Yield 89\%; M.P.: $168-169^{\circ} \mathrm{C}, \operatorname{IR}\left(\mathrm{cm}^{-1}\right):: 3190.5240,2949.5435,1731.1042$, $1685.6272,1656.7267,1600.7740,1558.4428,1542.34211522 .2959$. ${ }^{1} \mathrm{H}-\mathrm{NMR}(400 \mathrm{MHz}, \mathrm{DMSO}) \delta$ 7.59-7.50 (m, 2H), 7.30-7.18 (m, 2H), $7.05(\mathrm{t}, J=7.9 \mathrm{~Hz}, 1 \mathrm{H}), 6.71(\mathrm{dd}, J=8.1,2.4 \mathrm{~Hz}, 1 \mathrm{H}), 4.65(\mathrm{~s}, 2 \mathrm{H}), 4.36$ $(\mathrm{t}, J=6.5 \mathrm{~Hz}, 2 \mathrm{H}), 3.62(\mathrm{t}, 4 \mathrm{H}), 3.20(\mathrm{t}, J=6.5 \mathrm{~Hz}, 2 \mathrm{H}), 2.83(\mathrm{t}, 4 \mathrm{H})$. ESI-MS: $\mathrm{M}+1 \mathrm{M} / z 374.87$.

3-(2-(thiophen-2-yl)ethylimino)-5-fluoro-1-((4-methylpiperazin-1-yl) methyl)indolin-2-one (ITF 8)

Yield: $78 \%$; M.P. $167-169^{\circ} \mathrm{C}, \operatorname{IR}\left(\mathrm{cm}^{-1}\right): 3051.5657,2823.3506,1728.9289$, $1602.9915,1496.1849,1268.4834,919.2086,793.4854,{ }^{1} \mathrm{H}-\mathrm{NMR}(400 \mathrm{MHz}$, DMSO) $\delta 7.65-7.56(\mathrm{~m}, 2 \mathrm{H}), 7.34-7.22(\mathrm{~m}, 2 \mathrm{H}), 6.95(\mathrm{t}, J=7.8 \mathrm{~Hz}, 1 \mathrm{H})$, $6.71(\mathrm{dd}, J=8.4,2.4 \mathrm{~Hz}, 1 \mathrm{H}), 4.73(\mathrm{~s}, 2 \mathrm{H}), 4.45(\mathrm{t}, J=6.5 \mathrm{~Hz}, 2 \mathrm{H}), 3.36$ $(\mathrm{t}, J=6.5 \mathrm{~Hz}, 2 \mathrm{H}), 2.71(\mathrm{t}, 4 \mathrm{H}), 2.61(\mathrm{t}, 4 \mathrm{H}), 2.31(\mathrm{~s}, 3 \mathrm{H}) .{ }^{13} \mathrm{C}-\mathrm{NMR}$ $\left(126 \mathrm{MHz}, \mathrm{CDCl}_{3}\right) \delta 168.77,157.63,153.60,142.38,140.53,137.35$, $128.94,128.87,127.12,127.06,126.69,112.78,59.60,42.19,40.62,29.72$, 22.08, 15.07, ESI-MS: $\mathrm{M}+1 \mathrm{M} / z 387.66$

\section{In vitro anti-inflammatory activity}

The anti-inflammatory activity of conjugates was investigated by analyzing percentage inhibition of denaturation of the BSA technique ${ }^{19,25-28}$ using the reported method. The sample containing test compound and $1 \%$ aqueous solution of the BSA fraction was prepared and the $\mathrm{pH}$ of the mixture was adjusted to $\mathrm{pH} 6.3$ using a small amount of dilute hydrochloric acid. ( $0.05 \mathrm{ml}$ of saline solution was used in place of the drug in the control sample). Further, test samples were incubated for $20 \mathrm{~min}$, and then, the mixture was heated to $57^{\circ} \mathrm{C}$ for $20 \mathrm{~min}$. After cooling and the turbidity of the sample was measured at $660 \mathrm{~nm}$ using a spectrophotometer. The diclofenac sodium was used as the standard drug. The anti-inflammatory activities of the conjugates were estimated based on the percentage of inhibition of albumin denaturation using the following equation,

$\%$ inhibition $=[($ control absorbance-sample absorbance $) /$ control absorbance $]^{\star} 100$ 


\section{Antitubercular activity}

The anti-tubercular activity of conjugates was performed against Mycobacterium tuberculosis (H37 RV strain, ATCC 27294). Sterile deionized water of $200 \mu \mathrm{l}$ was added to outer perimeter wells to reduce evaporation of medium in the test wells during incubation. The wells plate filled with $100 \mu \mathrm{l}$ of the Middlebrook 7H9 broth and serial dilution of samples were made on the plate. The final compound concentrations investigated were 100 to $0.2 \mu \mathrm{g} / \mathrm{ml}$. Plates were covered with parafilm and incubated at $37^{\circ} \mathrm{C}$ for five days. After that, $25 \mu$ of prepared $1: 1$ mixture of Almar Blue reagent and $10 \%$ tween 80 was added to the plate and incubated for $24 \mathrm{hr}$. The blue color in the well indicated no bacterial growth, and the pink color indicated the growth of strain. The MIC values were calculated to study the inhibition at minimum concentrations. ${ }^{29}$

\section{Molecular docking}

The molecular docking study was performed on the PyRx suite based on the Autodock program ${ }^{30,31}$ and visualization in Discovery studio visualizer v19.1.0.18287. For docking analysis, PDB: 3LN1 was selected from the RCSB protein data bank (https://www.rcsb.org) with a resolution: 2.4 A. PDB: 3LN1 is a structure of celecoxib structure bound at the COX-2 binding site. For docking analysis, the protein file was prepared by adding missing atoms and residues in the receptor structure. Grid for docking study was selected where the co-crystallized was ligand bound. Interactions exhibited with the designed molecules and co-crystallized ligand with protein were studied.

\section{In silico ADME and Drug-likeness study}

The factor affecting ADME such as Hydrogen Bond Donors (HBD), Hydrogen Bond Acceptors (HBA), Gastrointestinal (GI) absorption, Log P, CYP2C19 inhibition, CYP2C9 inhibition, CYP3A4 inhibition, etc, were analyzed on the online server SwissADME (http://www.swissadme.ch/)..$^{32,33}$

\section{RESULTS}

\section{Chemistry}

Schiff's base was synthesized by treating dissolved 5-Fluoroisatin in warm ethanol with thiophene-2-ethylamine using two drops of glacial acetic acid (GAA) as a catalyst. (Scheme 1) The conjugates ITF 2- ITF 8 were synthesized by reacting synthesized Shiff base with an excess of $37 \%$ formaldehyde and secondary amines equimolar to Schiff base. The yields of synthesized compounds were in the range of $67-88 \%$.

\section{Anti-inflammatory activity}

Synthesized conjugates were tested for their in vitro anti-inflammatory activity against BSA. Among the synthesized conjugates, ITF 5 showed the highest percentage inhibition. The compounds ITF 1-ITF 8 showed good percentage inhibition as compared to standard. (Figure 1) (Table 1). The compounds showed weak to good antitubercular activity against the strain of MTB H37R . The compound containing N-phenylpiperazine Mannich base (ITF 5) exhibited inhibition of growth above $6.25 \mu \mathrm{g} / \mathrm{ml}$. (Table 2)

\section{Docking}

The Molecular docking study of conjugates was carried out using COX-2 enzyme structure as target (PDB: 3LN1). The binding site contains VAL509, ALA513, LEU520, PHE367, PHE191, PHE195, SER516, TYR371, VAL335, GLY512, PHE504, MET508, LEU338, ALA502, ARG499, and HIS75 in the proximity of $4 \AA$.

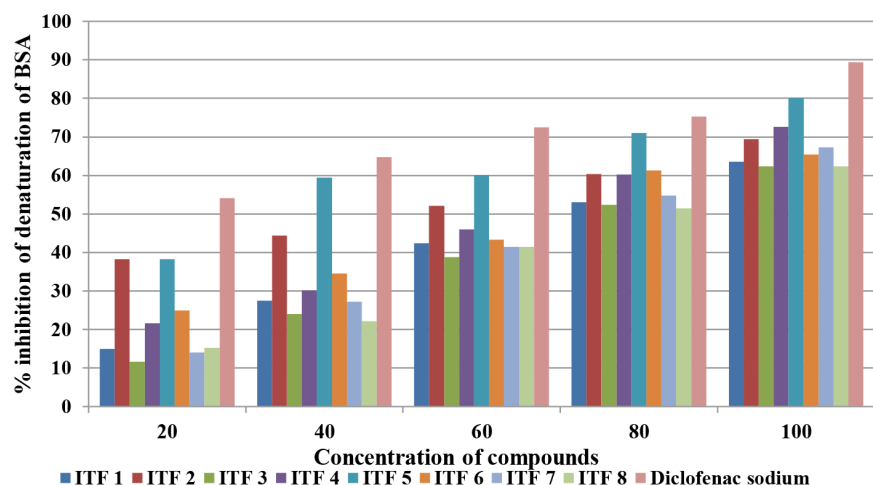

Figure 1: Anti-inflammatory activity of compounds.

Table 1: Anti-inflammatory activity of the compounds.

\begin{tabular}{|c|c|c|c|c|c|c|}
\hline \multirow{2}{*}{ Comp. } & \multicolumn{5}{|c|}{$\%$ inhibition of BSA denaturation } & \multirow{2}{*}{ - 을 } \\
\hline & $20 \mu \mathrm{g} / \mathrm{mL}$ & $40 \mu \mathrm{g} / \mathrm{mL}$ & $60 \mu \mathrm{g} / \mathrm{mL}$ & $80 \mu \mathrm{g} / \mathrm{mL}$ & $100 \mu \mathrm{g} / \mathrm{mL}$ & \\
\hline ITF 1 & 14.95 & 27.52 & 42.38 & 53.00 & 63.53 & -8.4 \\
\hline ITF 2 & 38.23 & 44.33 & 52.12 & 60.35 & 69.46 & -8.2 \\
\hline ITF 3 & 11.68 & 23.98 & 38.84 & 52.38 & 62.38 & -8.2 \\
\hline ITF 4 & 21.68 & 30.08 & 45.92 & 60.17 & 72.56 & -9.3 \\
\hline ITF 5 & 38.23 & 59.38 & 60.08 & 70.97 & 80.08 & -8.7 \\
\hline ITF 6 & 24.95 & 34.60 & 43.27 & 61.23 & 65.39 & -8.2 \\
\hline ITF 7 & 14.07 & 27.16 & 41.50 & 54.77 & 67.25 & -8.4 \\
\hline ITF 8 & 15.22 & 22.21 & 41.50 & 51.50 & 62.38 & -7.9 \\
\hline $\begin{array}{l}\text { Diclofenac } \\
\text { sodium }\end{array}$ & 54.15 & 64.69 & 72.47 & 75.22 & 89.38 & -9.3 \\
\hline
\end{tabular}

$\%$ : Percentage, *: Lower binding energy values indicate higher docking score

\section{In silico ADME}

All of the compounds were found to be within the permissible druglikeness parameters, which include M.W., HBD, HBA, and log P. ${ }^{34}$ The conjugates were predicted to have high gastrointestinal absorption. Except conjugate ITF 4, all the compounds are predicted as (Blood Brain Barrier) BBB permeants.

\section{DISCUSSION}

The synthesis procedures of isatin Schiff and Mannich bases reported in the literature were referred to synthesize the molecule of the present research work. ${ }^{21-24}$ The synthesis of Schiff base conjugate of 5-Fluoroisatin with thiophene-2-ethylamine and its Mannich bases was efficiently accomplished using the reported method. The Schiff base conjugate was synthesized by commonly used procedures. Glacial acetic acid as catalyst and followed by continuous stirring was done to synthesize the Schiff base of 5-Fluoroisatin and thiophene-2-ethylamine. For the synthesis of Mannich bases, the very slow speed of stirring (60 RPM) and slow addition of secondary amine with cooling in an ice bath is important while performing the reaction followed by recrystallization from chloroform and non-polar solvents like hexane or petroleum ether. Some modifications in reported methods were performed to carry out synthesis with good yield. The singlet at 4.5 to $5.0 \mathrm{\delta ppm}$ having integration of two hydrogen equivalents in ${ }^{1} \mathrm{H}$ NMR confirms the Mannich base formation. 
In IR spectra the peak at the carbonyl region shows the presence of $-\mathrm{N}$ $\mathrm{C}=\mathrm{O}$ group of the 5 -Fluoroisatin moiety.

Indomethacin and tenidap are known NSAIDs having indole nucleus and having substituents at C-3, C-5, and the nitrogen atom of indole moiety. ${ }^{35,36}$ The molecules of the present research work are designed based on studying these features. The interaction of clinically proven anti-inflammatory medicines with certain proteins has shown that these medicines actively inhibit the denaturation of protein. ${ }^{19}$ The estimation of compounds potential of inhibition of denaturation Bovine Serum Albumin is considered a method for anti-inflammatory activity study. ${ }^{25}$ The Piperazine containing compounds ITF 4, ITF 5, and ITF 8 showed

\section{Table 2: Antitubercular activity of compounds.}

\begin{tabular}{cccccccccc}
\hline $\begin{array}{c}\text { Sr. } \\
\text { No. }\end{array}$ & $\begin{array}{c}\text { Sample } \\
\text { code }\end{array}$ & $\begin{array}{c}100 \\
\mu \mathrm{g} / \\
\mathrm{ml}\end{array}$ & $\begin{array}{c}50 \\
\mu \mathrm{g} / \\
\mathrm{ml}\end{array}$ & $\begin{array}{c}25 \\
\mu \mathrm{g} / \\
\mathrm{ml}\end{array}$ & $\begin{array}{c}12.5 \\
\mu \mathrm{g} / \\
\mathrm{ml}\end{array}$ & $\begin{array}{c}6.25 \\
\mu \mathrm{g} / \\
\mathrm{ml}\end{array}$ & $\begin{array}{c}3.12 \\
\mu \mathrm{g} / \\
\mathrm{ml}\end{array}$ & $\begin{array}{c}1.6 \\
\mu \mathrm{g} / \\
\mathrm{ml}\end{array}$ & $\begin{array}{c}0.8 \\
\mathrm{mg} /\end{array}$ \\
\hline 1 & ITF 1 & $\mathrm{S}$ & $\mathrm{S}$ & $\mathrm{R}$ & $\mathrm{R}$ & $\mathrm{R}$ & $\mathrm{R}$ & $\mathrm{R}$ & $\mathrm{R}$ \\
2 & ITF 2 & $\mathrm{S}$ & $\mathrm{S}$ & $\mathrm{R}$ & $\mathrm{R}$ & $\mathrm{R}$ & $\mathrm{R}$ & $\mathrm{R}$ & $\mathrm{R}$ \\
3 & ITF 3 & $\mathrm{S}$ & $\mathrm{S}$ & $\mathrm{R}$ & $\mathrm{R}$ & $\mathrm{R}$ & $\mathrm{R}$ & $\mathrm{R}$ & $\mathrm{R}$ \\
4 & ITF 4 & $\mathrm{S}$ & $\mathrm{S}$ & $\mathrm{S}$ & $\mathrm{R}$ & $\mathrm{R}$ & $\mathrm{R}$ & $\mathrm{R}$ & $\mathrm{R}$ \\
5 & ITF 5 & $\mathrm{S}$ & $\mathrm{S}$ & $\mathrm{S}$ & $\mathrm{S}$ & $\mathrm{S}$ & $\mathrm{R}$ & $\mathrm{R}$ & $\mathrm{R}$ \\
6 & ITF 6 & $\mathrm{S}$ & $\mathrm{S}$ & $\mathrm{R}$ & $\mathrm{R}$ & $\mathrm{R}$ & $\mathrm{R}$ & $\mathrm{R}$ & $\mathrm{R}$ \\
7 & ITF 7 & $\mathrm{S}$ & $\mathrm{S}$ & $\mathrm{S}$ & $\mathrm{S}$ & $\mathrm{R}$ & $\mathrm{R}$ & $\mathrm{R}$ & $\mathrm{R}$ \\
8 & ITF 8 & $\mathrm{S}$ & $\mathrm{S}$ & $\mathrm{S}$ & $\mathrm{S}$ & $\mathrm{R}$ & $\mathrm{R}$ & $\mathrm{R}$ & $\mathrm{R}$ \\
9 & Isoniazid & $\mathrm{S}$ & $\mathrm{S}$ & $\mathrm{S}$ & $\mathrm{S}$ & $\mathrm{S}$ & $\mathrm{S}$ & $\mathrm{S}$ & $\mathrm{R}$ \\
\hline
\end{tabular}

S: Sensitivity, R: Resistance, Sensitivity at lower concentration indicates better activity

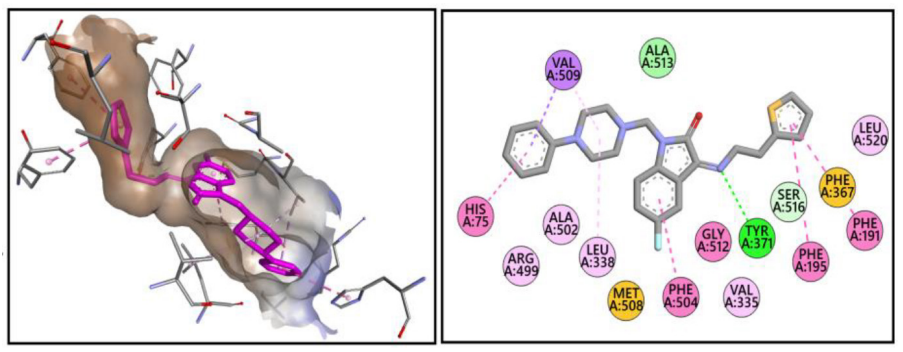

Figure 2: Docking pose and 2D interaction diagram of ITF 7.
72.56, 80.08, and $62.38 \%$ inhibition, respectively, where the standard drug diclofenac sodium showed $89.38 \%$ inhibition of denaturation of bovine serum albumin. (Table 1) It can be concluded from the structure-activity (SAR) analysis that the substitution of N-phenyl Piperazine containing Mannich bases favors the inflammatory activity of synthesized Schiff base conjugate of 5-Fluoroisatin with thiophene-2-ethylamine. The compound containing methyl group at the nitrogen of piperazine leads to decrement in activity as compared to unsubstituted nitrogen atom having molecule. (Figure 1)

The Mannich bases of isatin-Schiff base conjugates are reported in literature mainly for their potent anti-tubercular activities. ${ }^{22,23}$ The substitution of morpholine and piperazine containing substituents as Mannich base substrate also improves the anti-tubercular activity substantially. The Mannich bases derivatives containing substituents like pyrrolidine, diethylamine, and piperidine did not show improvement in inhibition of growth of MTB H37Rv strain. The N-phenyl piperazine containing compound ITF 5 (inhibition up to $6.25 \mu \mathrm{g} / \mathrm{ml}$ ) shows the highest activity where standard drug isoniazid showed inhibition of growth of MTB H37Rv strain up to $1.6 \mu \mathrm{g} / \mathrm{ml}$. From the SAR it can be stated that hydrophobic groups like phenyl ring at the nitrogen atom of piperazine ring may improve the anti-tubercular activity (Table 2).

A significant number of hydrophobic sites were detected during the binding site study, indicating that the binding site has a high potential for hydrophobic interaction. Conjugates (ITF 1- ITF 8) have shown significant interactions at the binding site amino acids. (Figure 2) The binding energies were found in the range of -7.9 to -9.3 . The most active compound ITF 5 showed a better binding energy score as compared to other compounds.

More than half of the candidates in drug development failed due to ADME insufficiencies. To avoid such failures, ADME screens are necessary to analyse for the compounds in the discovery process to eliminate those that are likely to fail later. ${ }^{37}$ To evaluate the drug-likeness and ADME various parameters were studied. All of the compounds were found to be within the permissible according to Lipinski's rule of five. All the conjugates were predicted as inhibitors of CYP2C19, CYP2C9, and CYP3A4 enzymes. (Table 3)

\section{CONCLUSION}

The conjugate ITF 5 was found to be the most effective against MTB $\mathrm{h} 37 \mathrm{Rv}$ and to inhibit BSA denaturation better than any other synthesized compound. The compound ITF 5 showed $80.08 \%$ inhibition of BSA denaturation at $100 \mu \mathrm{g} / \mathrm{mL}$ and showed the inhibition of growth of MTB h37Rv up to $6.25 \mu \mathrm{g} / \mathrm{ml}$. It can be concluded that the Mannich bases of 5-Fluoroisatin-thiophene-2-ethylamine Schiff base conjugate with

Table 3: In silico ADME properties of the compounds.

\begin{tabular}{|c|c|c|c|c|c|c|c|c|c|c|}
\hline Comp. & M.W. & HBA & HBD & iLOGP & $\begin{array}{c}\text { GI } \\
\text { Absorption }\end{array}$ & $\begin{array}{c}\text { BBB } \\
\text { permeant }\end{array}$ & $\begin{array}{l}\text { CYP1A2 } \\
\text { inhibitor }\end{array}$ & $\begin{array}{l}\text { CYP2C19 } \\
\text { inhibitor }\end{array}$ & $\begin{array}{l}\text { CYP2C9 } \\
\text { inhibitor }\end{array}$ & $\begin{array}{l}\text { CYP3A4 } \\
\text { inhibitor }\end{array}$ \\
\hline ITF 1 & 274.31 & 3 & 1 & 2.45 & High & Yes & Yes & Yes & Yes & Yes \\
\hline ITF 2 & 359.46 & 4 & 0 & 3.42 & High & Yes & Yes & Yes & Yes & Yes \\
\hline ITF 3 & 357.45 & 4 & 0 & 3.15 & High & Yes & Yes & Yes & Yes & Yes \\
\hline ITF 4 & 372.46 & 5 & 1 & 3.35 & High & No & Yes & Yes & Yes & Yes \\
\hline ITF 5 & 448.56 & 4 & 0 & 3.62 & High & Yes & No & Yes & Yes & Yes \\
\hline ITF 6 & 371.47 & 4 & 0 & 3.9 & High & Yes & Yes & Yes & Yes & Yes \\
\hline ITF 7 & 373.44 & 5 & 0 & 3.63 & High & Yes & Yes & Yes & Yes & Yes \\
\hline ITF 8 & 386.49 & 5 & 0 & 3.71 & High & Yes & Yes & Yes & Yes & Yes \\
\hline
\end{tabular}


Varpe and Jadhav.: Pharmacological activity of Schiff Base of 5-Fluoroisatin with Thiophene-2-Ethylamine and its Mannich Bases

piperazine containing compounds and hydrophobic substituents on Piperazine ring could improve the anti-TB and anti-inflammatory activities. Docking analysis revealed that the compounds show good interactions with the COX-2 enzyme binding site.

\section{ACKNOWLEDGEMENT}

Authors are thankful to Dr. Kishore G. Bhat, Department of Microbiology, Maratha Mandal's NGH Institute of Dental Sciences and Research Centre, Belgaum, Karnataka, India, for proving antitubercular activity study.

\section{CONFLICT OF INTEREST}

The authors declare no conflict of interest.

\section{ABBREVIATIONS}

ADME: Absorption, Distribution, Metabolism, and Excretion; MTB: Mycobacterium tuberculosis; SAR: Structure-Activity Relationship; BSA: Bovine Serum Albumin; MP: Melting Point; IR: Infra-Red; UV: Ultraviolet; COX-2: Cyclooxygenase-2; RPM: Revolutions Per Minute; NMR: Nuclear Magnetic Resonance; MS: Mass Spectroscopy; CHN: Carbon, Hydrogen, Nitrogen; ${ }^{1} \mathbf{H}$-NMR: Proton Nuclear Magnetic Resonance; ${ }^{13}$ C-NMR: Carbon-13 Nuclear Magnetic Resonance; $\mathbf{C D C l}_{3}$ : Deuterated Chloroform; DMSO: Dimethyl Sulfoxide; PDB: Protein Data Bank; M.W.: Molecular Weight; IlogP: Partition Coefficient; HBA: Hydrogen Bond Acceptors; HBD: Hydrogen Bond Donors.

\section{REFERENCES}

1. Xu Z, Zhang S, Song $X$, Qiang M, Lv Z. Design, synthesis and in vitro antimycobacterial evaluation of gatifloxacin-1H-1,2,3-triazole-isatin hybrids. Bioorg Med Chem Lett. 2017;27(16):3643-6. doi: 10.1016/j.bmcl.2017.07.023, PMID 28720502.

2. Deng JL, Liu XC, Cai GW, et al, Zhang G, Hu L, Qiu L, Li Z, Xu Z. Heteronuclear 5-Fluoroisatin Dimers: Ddesign, Synthesis, and Evaluation of Their in vitro Aantimycobacterial Activities. J Heterocycl Chem. 2018;55(6):1509-13. doi: 10.1002/ jhet.3186

3. Liu B, Wang GQ, Peng YH, Tang XQ, Hu GW. Design, synthesis, and in vitro antimycobacterial activities of butylene tethered 7-fluoroisatin-isatin scaffolds. J Heterocycl Chem. 2019;56(12):3423-28. doi: 10.1002/jhet.3696.

4. Prakash CR, Raja S. Synthesis, characterization and in vitro antimicrobial activity of some novel 5-substituted Schiff and Mannich base of isatin derivatives. J Saudi Chem Soc. 2013;17(3):337-44. doi: 10.1016/j.jscs.2011.10.022.

5. Varpe BD, Kulkarni AA, Jadhav SB, Mali AS, Jadhav SY. Isatin hybrids and Their Pharmacological Investigations. Mini Rev Med Chem. 20212020;21(10):1182 1225. doi: 10.2174/1389557520999201209213029, PMID 33302835.

6. El-Sedik M, Abd Elmegied S, Aysha T, Mahmoud S. Synthesis and application of new reactive disperse dyes based on isatin derivatives and their Aantibacterial activity. Egypt J Chem. 2019;62(12):2253-640. doi: 10.21608/ ejchem.2019.12976.1810.

7. Selvam TP, Kumar PV, Saravanan G, Prakash CR. Microwave-assisted synthesis, characterization and biological activity of novel pyrazole derivatives. J Saudi Chem Soc. 2014;18(6):1015-21. doi: 10.1016/j.jscs.2011.12.006.

8. Sriram D, Yogeeswari P, Meena K. Synthesis, anti-HIV and antitubercular activities of isatin derivatives. Pharmazie. 2006;61(4):274-77. doi: 10.1002/ chin.200629154, PMID 16649536.

9. Lu X, Tang J, You Q, Wan B, G Franzblau S S. Design, Synthesis and Antitubercular Evaluation of New 2-amino-5-(4-(benzyloxy) benzyl) thiophene-3-carboxylic Acid Derivatives. Part 3. Lett Drug Des Discov. 2015;12(1):29-37. doi: 10.2174/15701 80811666140812231321

10. Liu R, Lyu X, Batt SM, Hsu MH, Harbut MB, Vilchèze $C$, et al. Determinants of the linhibition of DprE1 and CYP2C9 by Aantitubercular Tthiophenes. Angew Chemie Int Ed Engl. 2017;56(42):13011-5. doi: 10.1002/anie.201707324, PMID 28815830

11. Parai MK, Panda G, Chaturvedi V, Manju YK, Sinha S. Thiophene containing triarylmethanes as antitubercular agents. Bioorg Med Chem Lett. 2008;18(1):289-292. doi: 10.1016/j.bmcl.2007.10.083, PMID 17997304.

12. Jiang D, Wang GQ, Liu X, Zhang Z, Feng LS, Liu ML. Isatin Dderivatives with Ppotential Aantitubercular Aactivities. J Heterocycl Chem.. 2018;55(6):1263-79. doi: 10.1002/jhet.3189.

13. Amr AE-GE, Sabry NM, Abdulla MM. Synthesis, reactions, and anti-inflammatory activity of heterocyclic systems fused to a thiophene moiety using citrazinic acid as sSynthon. Monatshefte für Chemie-Chemical Mon. 2007;138(7):699-707. doi: 10.1007/s00706-007-0651-0.

14. Kumar PR, Raju S, Goud PS, Sailaja M, Sarma MR, Reddy GO, et al. Synthesis and biological evaluation of thiophene $[3,2-b]$ pyrrole derivatives as potential anti-inflammatory agents. Bioorg Med Chem. 2004;12(5):1221-30. doi: 10.1016/j. bmc.2003.11.003, PMID 14980634.

15. Hwang SH, TWecksler AT, Wagner K, Hammock BD. A, Wagner K, D Hammock B Rationally designed multitarget agents against inflammation and pain. Curr Med Chem. 2013;20(13):1783-99. doi: 10.2174/0929867311320130013, PMID 23410172

16. Wylie G, Appelboom T, Bolten W, Breedveld FC, Feely J, Leeming MR, et al. A comparative study of tenidap, a cytokine-modulating anti-rheumatic drug, and diclofenac in rheumatoid arthritis: a 24-week analysis of a 1-year clinical trial. Br J Rheumatology. 1995;34(6):554-63. doi: 10.1093/rheumatology/34.6.554, PMID 7543348.

17. Jadhav SY, Peerzade NA, Hublikar MG, Varpe BD, Kulkarni AA, Bhosale RB. Synthesis and Ppharmacological Sscreening of Ddifluorophenyl Ppyrazole Cchalcone Cconjugates as Aantifungal, Aanti-linflammatory, and Aantioxidant Aagents. Russ J Bioorganic Chem. 2020;46(6):1128-35. doi: 10.1134/ S1068162020060102.

18. Chandra S, Chatterjee P, Dey P, Bhattacharya S. Evaluation of in vitro anti-inflammatory activity of coffee against the denaturation of protein. Asian Pac J Trop Biomed. 2012:2(1):S178-S180. doi: 10.1016/S2221-1691(12)60154-3.

19. Mizushima $Y$, Kobayashi M. Interaction of anti-inflammatory drugs with serum proteins, especially with some biologically active proteins. J Pharm Pharmacol. 1968;20(3):169-173. doi: 10.1111/j.2042-7158.1968.tb09718.x, PMID 4385045.

20. Opie EL. On the relation of necrosis and inflammation to denaturation of proteins. J Exp Med. 1962;115(3):597-608. doi: 10.1084/jem.115.3.597, PMID 14482110.

21. Pandeya SN, Sriram D, Nath G, Declercq E. Synthesis, antibacterial, antifungal and anti-HIV activities of Schiff and Mannich bases derived from isatin derivatives and N-[4-(4"'-chlorophenyl)thiazol-2-yl] thiosemicarbazide. Eur J Pharm Sci. 1999;9(1):25-31. doi: 10.1016/S0928-0987(99)00038-X.

22. Pandeya SN, Sriram D, Yogeeswari P, Ananthan S. Antituberculous activity of norfloxacin Mannich bases with isatin derivatives. Chemotherapy. 2001;47(4):266-269. doi: 10.1159/000048533, PMID 11399863.

23. Sriram D, Bal TR, Yogeeswari P. Synthesis, antiviral and antibacterial activities of isatin mannich bases. Med Chem Res. 2005;14(4):211-228. doi: 10.1007/ s00044-005-0135-x

24. Ozgun DO, Yamali C, Gul HI, et al, Taslimi P, Gulcin I, YanikT, Supuran CT. Inhibitory effects of isatin Mannich bases on carbonic anhydrases, acetylcholinesterase and butyrylcholinesterase. J Enzyme Inhib Med Chem. 2016;31(6):1498-1501. doi: 10.3109/14756366.2016.1149479, PMID 26928426.

25. Kamat V, Santosh R, Poojary B, Nayak SP, Kumar BK, et al. Pyridine- and Thiazole-Based Hydrazides with Promising Anti-inflammatory and Antimicrobial Activities along with Their in silico Studies. ACS Omega. 2020;5(39):25228-39. doi: 10.1021/acsomega.0c03386, PMID 33043201

26. Sakat S, Juvekar AR, Gambhire MN. In vitro antioxidant and anti-inflammatory activity of methanol extract of Oxalis corniculata Linn. Int J Pharm Pharm Sci. 2010:2(1):146-155.

27. Peerzade NA, Jadhav SY, Bhosale RB, Kulkarni AA, Varpe BD. Synthesis, docking, in silico ADMET and pharmacological evaluation of some N-acetyl pyrazole and quinoline conjugates. Lett Drug Des Discov. 2020;17(8):1015-1026. doi: 10.2174 /1570180817666200228123347.

28. Peerzade NA, Jadhav SY, Varpe BD, AmolKulkarni AA, Bhosale RB. Green Synthesis, Molecular Docking, in silico ADME and Biological Evaluation 'of Methoxy Substituted 1,5-Benzodiazepines as Potential Antioxidant, Anti-Inflammatory, and Antidiabetic Agents. Polycyclic Aromatic Compounds. $2021 ; 1$, 5-Benzodiazepines as Potential Antioxidant, AntiInflammatory, and Antidiabetic Agents. Polycycl Aromat Compd. 2021:1-14 doi: 10.1080/10406638.2021.1878244

29. Lourenço MCS, Souza MVNd, Pinheiro AC, Ferreira MdL, Gonçalves RSB, Nogueira TCM, Peralta MA. Evaluation of anti-tubercular activity of nicotinic and isoniazid analogues. Arkivoc. 2007(15):181-91. doi: 10.3998/ark.5550190.0008. f18.

30. Trott, O. Olson AJ. AutoDockVina: limproving the speed and accuracy of docking with a new scoring function, efficient optimization, and multithreading. J Comput Chem. 20092010;31(2):455-61. doi: 10.1002/jcc.21334, PMID 19499576.

31. Dallakyan S, Olson AJ. Small-molecule library screening by docking with PyRx. In:. ChemicaMethods Mol Biology. Springer. 2015;1263:243-50. doi: 10.1007/978-1-4939-2269-7_19, PMID 25618350.

32. Daina A, Michielin O, Zoete V. iLOGP: a simple, robust, and efficient description of n-octanol/water partition coefficient for drug design using the GB/SA approach. J Chem Inf Model. 2014;54(12):3284-301. doi: 10.1021/ci500467k PMID 25382374.

33. Daina A, Michielin O, Zoete V. SwissADME: a free web tool to evaluate pharmacokinetics, drug-likeness and medicinal chemistry friendliness of small molecules. [Ssci Rrep. :2017]. Sci Rep. 2017;7(1):1-13:42717. doi: 10.1038/srep42717, PMID 28256516

34. Jadhav SY, Peerzade NA, Gawali RG, Bhosale RB, Kulkarni AA, Varpe BD. Green synthesis and biological screening of some fluorinated pyrazole chalcones in 
search of potent anti-inflammatory and analgesic agents. Egypt Pharmaceut J. 2020;19(2):172-181. doi: 10.4103/epj.epj_64_19.

35. Moore PF, Larson DL, Otterness IG, et al, Weissman A, Kadin SB, Sweeney FJ, Eskra JD, Nagahisa A, Sakakibara M, Carty TJ. Tenidap, a structurally novel drug for the treatment of arthritis: antiinflammatory and analgesic properties. Inflamm Res. 1996:45(2):54-61. doi: 10.1007/BF02265116, PMID 8907585.
36. Goodman LS. Goodman and Gilman's the pharmacological basis of therapeutics. Vol. 1549. New York City, United States: McGraw-Hill New York; 1996.

37. Paul Gleeson MP, Hersey A, Hannongbua S. In-silico ADME models: a general assessment of their utility in drug discovery applications. Curr Top Med Chem. 2011:11(4):358-381. doi: 10.2174/156802611794480927, PMID 21320065.

Article History: Submission Date : 05-05-2021; Revised Date : 21-05-2021; Acceptance Date : 20-06-2021.

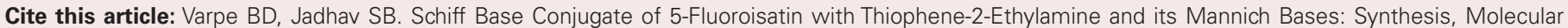
Docking, and Evaluation of in vitro Anti-inflammatory and Anti-tubercular Activity. Int. J. Pharm. Investigation. 2021;11(2):189-94. 